\title{
Observations of the Summer Birds of Tukarak Island (Belcher Islands, Nunavut), Nastapoka Islands (Nunavut), and Lac Guillaume-Delisle (Northern Quebec)
}

\author{
Christopher W. SWarth ${ }^{1,3}$ and Wouter BleEKER ${ }^{2}$ \\ ${ }^{1}$ Natural Reserve System, University of California, Merced, California 95343 USA \\ ${ }^{2}$ Geological Survey of Canada, Ottawa, Ontario Canada \\ ${ }^{3}$ Corresponding author: cswarth@ucmerced.edu
}

Swarth, Christopher W., and Wouter Bleeker. 2014. Observations of the summer birds of Tukarak Island (Belcher Islands, Nunavut), Nastapoka Islands (Nunavut), and Lac Guillaume-Delisle (northern Quebec). Canadian Field-Naturalist 128(4): 385-392.

In a survey of land and water birds of Tukarak and Nastapoka Islands and Lac Guillaume-Delisle in summer 2011, we recorded 22 of the 30 species known to breed on the Belcher Islands, as well as five non-breeding species, and we observed 32 species in Lac Guillaume-Delisle. In all areas surveyed, we observed a total of 43 species: 10 waterfowl, 2 gallinaceous birds, 3 loons, 2 hawks, 3 shorebirds, 1 auk, 3 gulls, 2 falcons, and 17 songbirds. In this area of Hudson Bay, a number of species reach the southern or northern limit of their breeding distribution in eastern Canada. In light of the impact that climate change may have on bird distribution in northerly latitudes, the Belcher Islands and adjacent mainland areas could be particularly useful locations for monitoring changes in the breeding range of birds.

Key Words: Breeding birds; Hudson Bay; Belcher Islands; Tukarak Island; Lac Guillaume-Delisle; Nastapoka Islands

\section{Introduction}

The breeding avifauna of the Belcher Islands, Nunavut, has been documented by Twomey (1942), Todd (1963), Freeman (1970), and Manning (1976). Twomey was the first to make systematic bird observations on the Belcher Islands, which he described in general terms in Needle to the North (Twomey 1942). On Tukarak and Flaherty Islands, Twomey collected 19 bird species (273 specimens and 59 clutches of eggs); his collection is held at the Carnegie Museum of Natural History, Pittsburgh, Pennsylvania. Freeman (1970) spent the summers of 1959 and 1960, and March and April 1961 in the area. Most of his observations were made in the southwest region of Flaherty Island near the mouth of the Kasegalik River, although he also visited Tukarak Island. Manning (1976) visited the islands from May to September 1971, principally to study polar bears, but he also collected birds and estimated the size of breeding populations. More recently, information on Common Eiders was summarized by Abraham and Finney (1986) and by Robertson and Gilchrist (1998). Arctic Tern and gull population trends on the Belcher Islands were described by Gilchrist and Robertson (1999). A checklist of the bird life of Nunavut (Richards and White 2008) is based on recent sightings from throughout this vast territory. A report by the Kativik Regional Government (KRG 2007) on plans to create national parks in the western Ungava Peninsula includes a list of birds of Lac Guillaume-Delisle. The Quebec Breeding Bird Atlas (www.atlas-oiseaux.qc.ca/index_en .jsp), now in its fifth year, is mapping recent sightings by birdwatchers to Lac Guillaume-Delisle.
This report summarizes bird observations made from 17 to 30 July 2011 in eastern Hudson Bay, Canada, specifically on Tukarak Island (Belcher Island group, Nunavut), on the Nastapoka Islands (Nunavut), and in Lac Guillaume-Delisle (northern Quebec). Considering the long periods between visits by ornithologists to these remote areas, our observations augment the earlier more lengthy surveys and contribute new knowledge of the bird life of this region.

\section{Study Area}

The Belcher Islands $\left(56^{\circ} 00^{\prime}\right.$ to $57^{\circ} 30^{\prime} \mathrm{N}, 79^{\circ} 30^{\prime}$ to $80^{\circ} 00^{\prime} \mathrm{W}$ ) comprise 1500 islands and islets covering almost $3000 \mathrm{~km}^{2}$ in eastern Hudson Bay (Figure 1a). They are located about $120 \mathrm{~km}$ off the eastern shore of Hudson Bay. This region is well north of the tree line. The only trees we observed on the Belcher Islands were low-growing willows (Salix spp.) and Paper Birch (Betula papyrifera Marshall). Also, the area around the town of Umiujaq on the mainland is mostly treeless. In contrast, Lac Guillaume-Delisle (Figure 1b) has extensive groves of spruce (Picea spp.), willow, and Green Alder (Alnus viridis [Chaix] de Candolle), especially in ravines and along the lower sections of streams.

\section{Methods}

In 2011, we visited Tukarak Island in the Belcher Islands group (17-24 July), Lac Guillaume-Delisle (2530 July), and several of the Nastapoka Islands near Umiujaq (25 and 30 July). Our primary purpose was to investigate geological formations in this region; however, each day we made a concerted effort to identify, count, and record all the birds in every area we visited. 


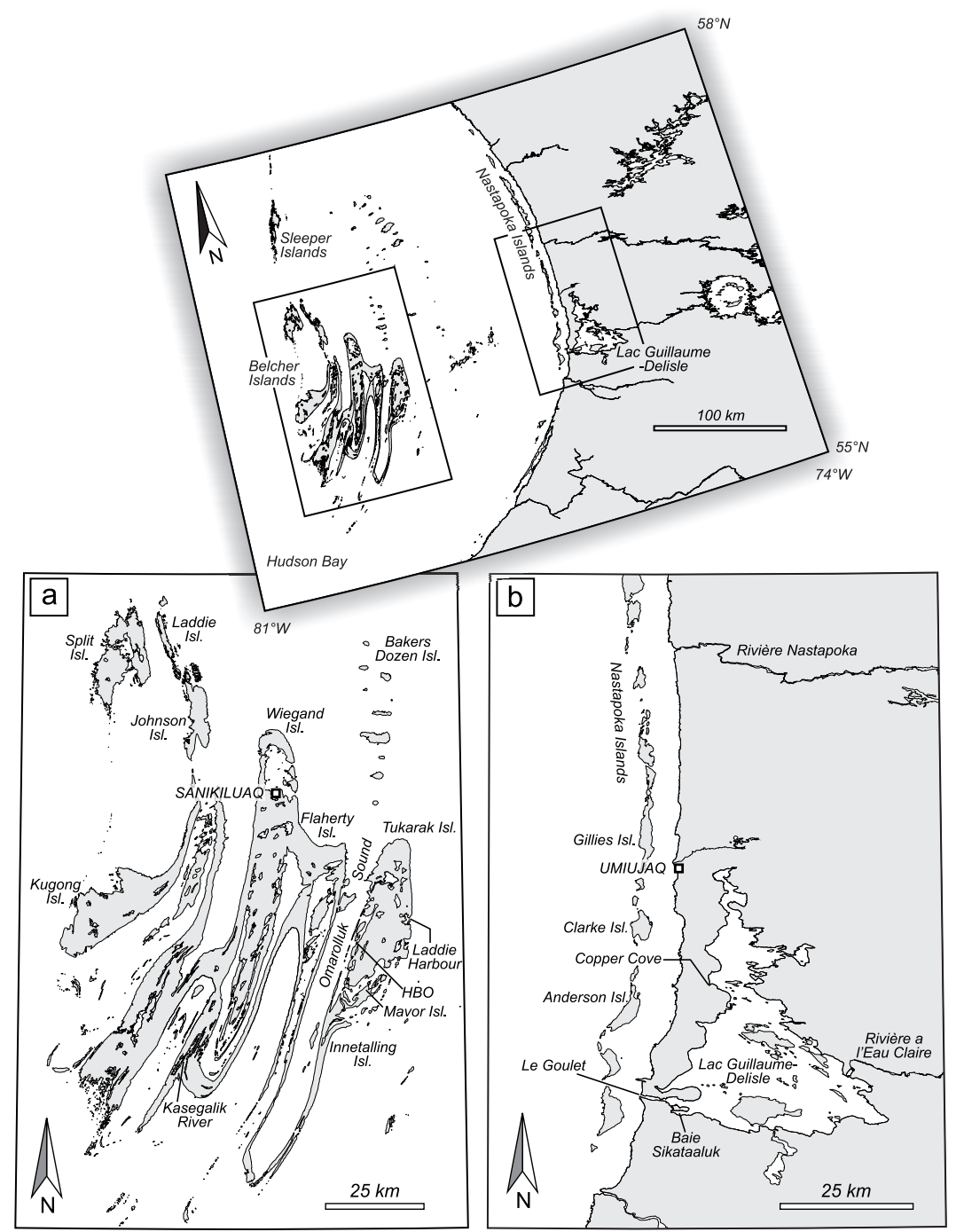

FIgURE 1. Locations of 2011 fieldwork in eastern Hudson Bay: Tukarak Island (Belcher Island group), Nunavut (a); Lac Guillaume-Delisle, Quebec; and the Nastapoka Islands, Nunavut (b). HBO = Hudson Bay outpost.

We traveled to and between the islands on the fishing boat, Kakivak, skippered by Inuit fishermen from Inukjuak, Quebec. While traveling across open water between shore-based sites, we maintained a constant watch and tallied all waterbirds visible from the boat. At night we anchored near shore, which provided excellent views of the rocky shorelines and beaches. Each day, we covered about $5-10 \mathrm{~km}$ on foot across a variety of habitats: dry and moist tundra, exposed rock formations, small streams, willow-covered ravines, and lakes, which we circumnavigated. We observed birds with $8 \times$ binoculars and a $20-60 \times$ spotting scope. The figures in the tables represent the sum total of independent daily surveys that were often, but not always, made separately by the two observers. We took care to avoid com- bining duplicate counts of the same birds. On the boat, the observers scanned the open waters from opposite sides of the boat. C.W.S. devoted about 12 hours each day to bird observations and W.B. about 6 hours.

Observations on Tukarak Island were concentrated in three areas: the southeast region; around the old Hudson Bay outpost along Omarolluk Sound on the west side; and at Laddie Harbour on the east-central side of the island (Figure 1a). We did not visit any of the small coastal islets.

In the Nastapoka Island group, we visited Clarke, Anderson, and Gillies Islands. In Lac GuillaumeDelisle, fieldwork took place in Baie Sikutaaluk near the Gulf ("Le Goulet"), south of the mouth of the 
Rivière à l'Eau Claire, and at Copper Cove on the west-central shore (Figure 1b).

\section{Results}

On the Belcher Islands, we observed 22 of the 30 species that are regular or occasional breeders there (Table 1). Breeding species not observed were King Eider (Somateria spectabilis), Long-tailed Duck (Clangula hyemalis), Semipalmated Sandpiper (Calidris pusilla), Red-necked Phalarope (Phalaropus lobatus), Parasitic Jaeger (Stercorarius parasiticus), Arctic Tern (Sterna paradisaea), Snowy Owl (Bubo scandiacus), and Common Redpoll (Carduelis flammea). We also observed five migrant, non-breeding species. The summer avifauna of the Lac Guillaume-Delisle region, in contrast, is richer than that of the Belcher Islands. In the former, we observed 22 species that breed in this region (including Umiujaq and the Nastapoka Islands) and 10 migrants (Table 2). In all areas surveyed, we observed a total of 43 species: 10 waterfowl, 2 gallinaceous birds, 3 loons, 2 hawks, 3 shorebirds, 1 auk, 3 gulls, 2 falcons, and 17 songbirds. Several sightings represent extra-limital records of birds well north of their regular breeding range. The notes that follow summarize details about these observations.

On Tukarak Island, we observed flocks of 164 and 200 flightless Canada Geese (Branta canadensis), adults and goslings, and a flock of about 200 on Clarke Island (Nastapoka Island group). We observed adult Tundra Swans (Cygnus columbianus) swimming on lakes on Tukarak Island, but we did not see any cygnets.

We saw Common Eiders (Somateria mollisima sedentaria) daily in the coastal waters around Tukarak Island and in Lac Guillaume-Delisle. No eiders were seen on any inland lakes and we saw no nests. In the waters around Tukarak Island, over $90 \%$ of males were in breeding plumage, and we observed many females there with broods of various ages. The first male seen in eclipse plumage near Tukarak Island was on $21 \mathrm{July}$, whereas all the males we identified in Lac GuillaumeDelisle were in eclipse plumage.

Three male Harlequin Ducks (Histrionicus histrionicus) were seen at Copper Cove, Lac Guillaume-Delisle, on two days; presumably the same group was seen each day.

Scoters were seen almost daily. Of those we were able to identify to species, Surf Scoters (Melanitta perspicillata) were the most abundant. The largest single flock of 1200 unidentified scoters was seen on Lac Guillaume-Delisle on 27 July. Black Scoters (M. americana) were seen on Lac Guillaume-Delisle, but not on Hudson Bay proper. The 30 Red-breasted Mergansers (Mergus serrator) in Lac Guillaume-Delisle on 27 July were flightless and in a single flock.

Two female Northern Harriers (Circus cyaneus) were seen on Lac Guillaume-Delisle on 27 July, and one female flying with prey was in Umiujaq on 30 July.

Spotted Sandpipers (Actitis macularius) were seen on four days along the shores of Lac Guillaume-Delisle.
An adult was attending three, one-third-grown chicks on 26 July.

Two Purple Sandpipers (Calidris maritima), the only ones seen during our trip, flew in and briefly mobbed us on Tukarak Island on 17 July.

Black Guillemots (Cepphus grylle) were observed around Tukarak Island and on Lac Guillaume-Delisle on 10 of 15 days for a mean of 27 per day. The highest daily counts were 88 near Tukarak Island and 61 on Lac Guillaume-Delisle. The guillemots were often in pairs, or in groups of 10 or fewer, and all were in breeding plumage. No birds were perched on rocks or cliffs, nor were any carrying food, and we saw no juveniles. These observations suggest that they were not nesting in these areas at this time.

Glaucous Gulls (Larus hyperboreus) were seen on eight days on Hudson Bay. The largest group was 10 at Laddie Harbour on 22 July, where several halfgrown chicks were seen on rocks near the water's edge. No Glaucous Gulls were seen on Lac GuillaumeDelisle. Great Black-backed Gulls (Larus marinus) were observed on five days. An adult pair was seen at Tukarak Island on 18 July and five (four adults and one third-year bird) were seen near the Nastapoka Islands on 25 July. We saw nothing to suggest that they had nests, and we saw no chicks.

Peregrine Falcons (Falco peregrinus) were seen at two locations on Tukarak Island. On 19 July one flew along the cliffs at the south end of the island. On 23 and 24 July, we observed a pair closely for several hours and photographed them at their nest at Laddie Harbour. The nest site was on a sparsely vegetated ledge on a vertical cliff, 7-10 $\mathrm{m}$ above the water at the head of a small cove. The nest held two downy young, which appeared to be several weeks old based on their size and white downy plumage, and a single egg. At one point, the male arrived clutching an adult Horned Lark (Eremophila alpestris).

Single Hermit Thrushes (Catharus guttatus) were seen and heard singing in a wooded area along the south shore of Lac Guillaume-Delisle on 25 and 27 July.

\section{Discussion}

Many bird species currently reach the northern or southern limit of their breeding range in the eastern Hudson Bay region (Godfrey 1986), making this area especially interesting from a zoogeographic perspective. However, range boundaries are rarely static and arctic regions are changing rapidly in response to climate change (Serrize et al. 2000; Comiso 2003). Bird populations, especially those at high latitudes, could undergo significant range shifts in the near future (Jetz et al. 2007).

Few ornithologists have visited the Belcher Islands, in part because of their remote location and the associated logistics and costs that make access difficult. Lac Guillaume-Delisle is also remote, although plans to create a national park there could increase visits in 


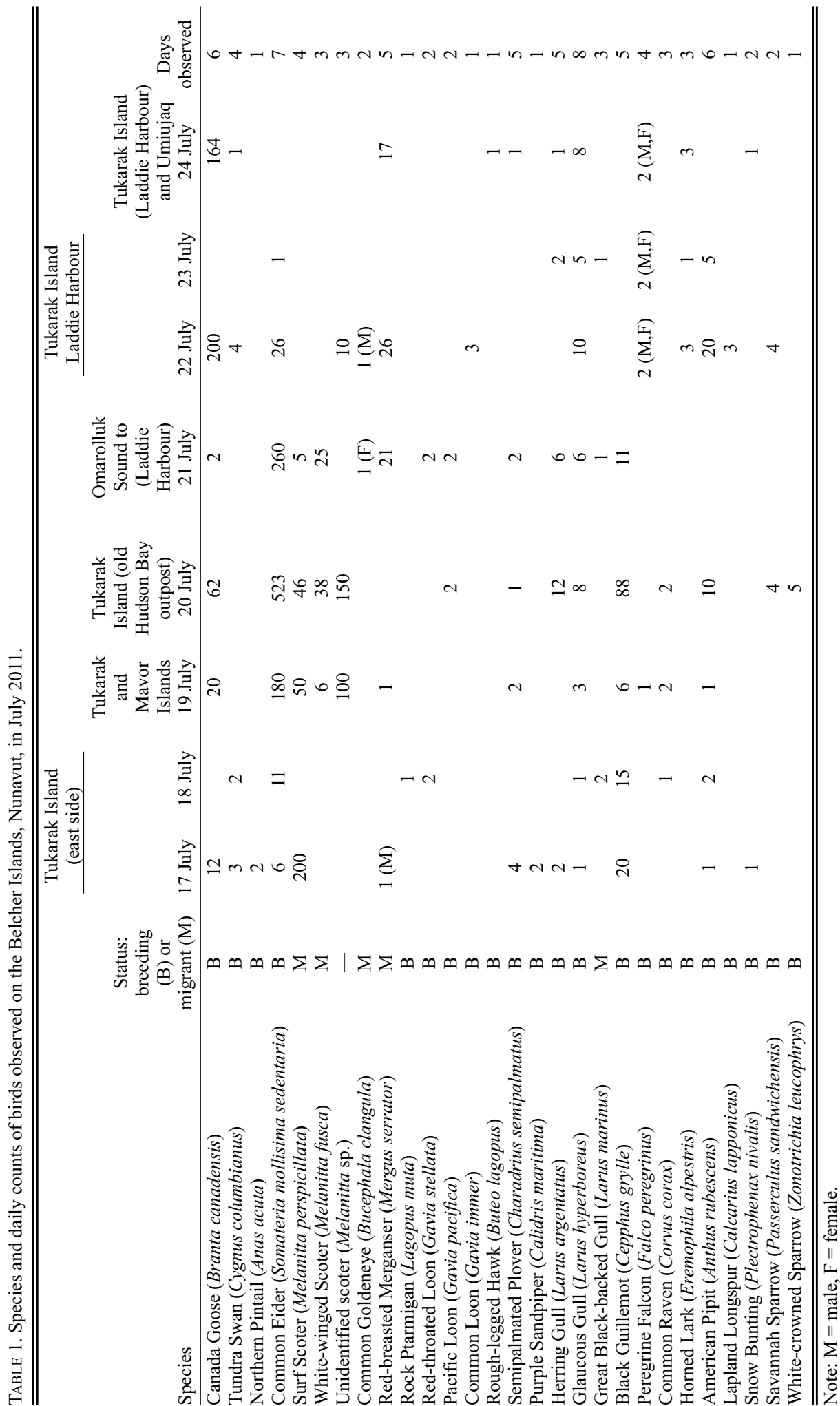




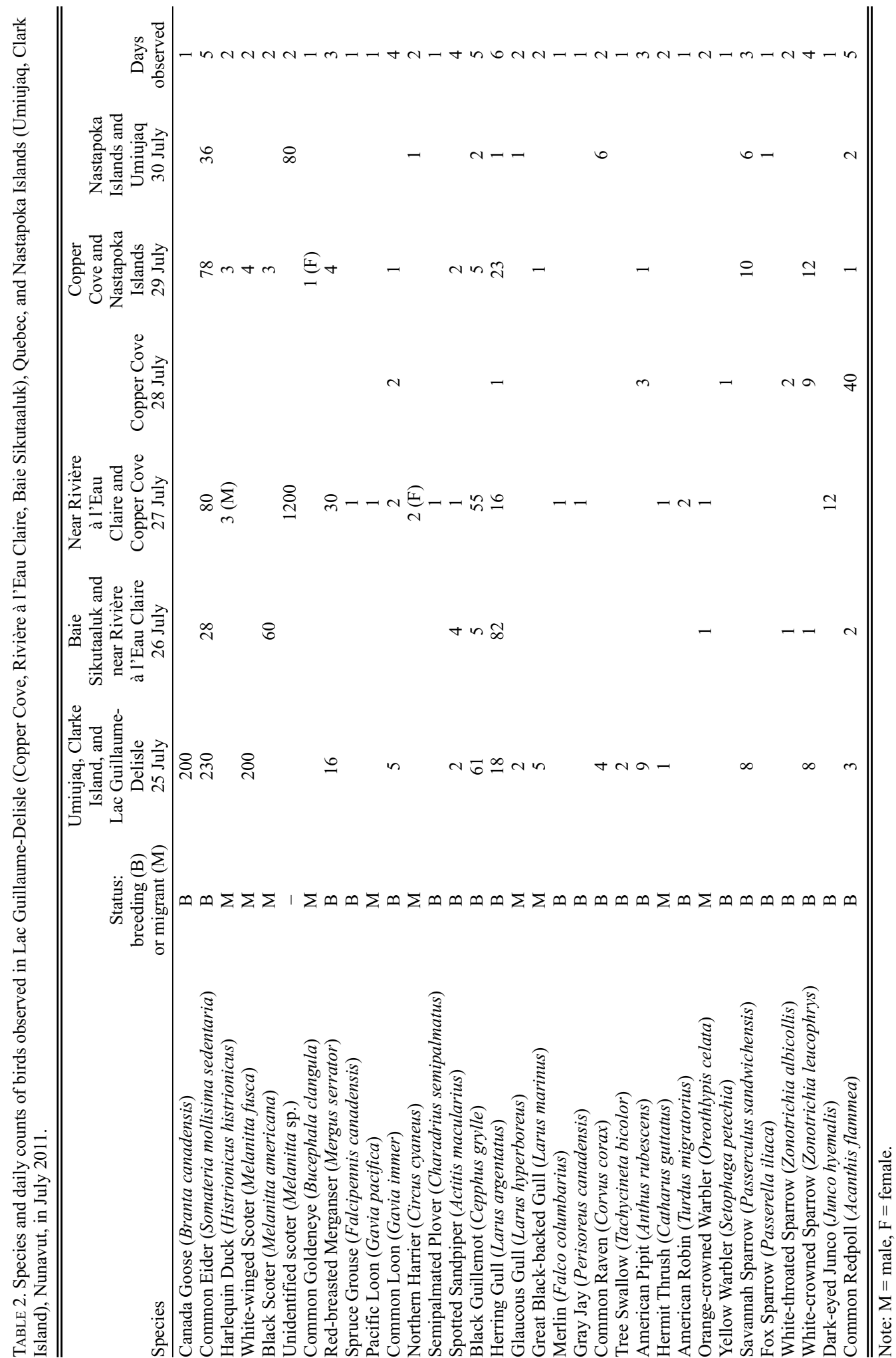


the near future. Knowledge of the summer bird life of the Belcher Islands and Lac Guillaume-Delisle is, therefore, based on just a few reports and publications that span many decades. Twomey's observations, summarized in a popular book (Twomey 1942), provide fascinating details about the bird life, but unfortunately the results of his extensive study were not published in the scientific literature. The reports of Thomas Manning (1946, 1976) were especially thorough, and the sightings by Freeman (1970) are also useful. Based on these publications, the regular breeding avifauna is considered to consist of about 30 species. The Quebec Breeding Bird Atlas project (www.atlas-oiseaux.qc.ca/index en.jsp) is compiling recent bird records from Lac Guillaume-Delisle, although there are few mapped sightings to date from this region. Our observational records add to the limited number of reports from eastern Hudson Bay and, especially, augment knowledge of the birds that breed or spend the summer around the Belcher Islands. Conversely, the lack of sightings of some probable breeding species such as Red-necked Phalaropes and Common Redpolls does not mean those species were not present during our visit.

We were not able to determine the age of the flightless Canada Geese in the flocks we observed on Tukarak Island and the Nastapoka Islands. Populations in late spring and summer are likely made up of both local breeders and of migrants from southern populations. Based on satellite radio telemetry, it is known that some geese that breed on the Atlantic flyway in eastern North America migrate in June to northern Quebec and the east coast of Hudson Bay (Sheaffer et al. 2007) where they undergo a complete annual molt.

Tundra Swans are irregular or uncommon breeders on the Belcher Islands, which are near the southern limit of their breeding range (Godfrey 1986). Freeman (1970) saw only one pair on the Belcher Islands in mid-June 1960, and he cites a report by Burwash (1927) that suggests that swans were scarce in this region by the mid1920s. Tundra Swans were common breeders along southern Hudson Bay in the 1800s, but heavy hunting greatly reduced their numbers thereafter. Swans did not begin to re-inhabit these areas until the 1960s (Lumsden 1975).

The sighting of three male Harlequin Ducks was fortuitous, but not unexpected as they are known to nest around Lac Guillaume-Delisle and north to the Nastapoka River (Robertson and Goudie 1999; KRG 2007).

The breeding ranges of the Surf Scoter and the Black Scoter in North America are imperfectly known (Savard et al. 1998); however, in eastern Canada the centre of abundance of both species is the Ungava Peninsula. White-winged Scoters breed to the south and west. There are no records of scoters breeding on the Belcher Islands and we saw nothing to suggest that they might have been nesting during our visit.

The three Northern Harriers observed represent extralimital records, well north of their published breeding range (Godfrey 1986; Smith et al 2011). In the Lac Guillaume-Delisle region, there is at least one recent nesting record (KRG 2007) and a single "possible nesting" record in the Quebec Breeding Bird Atlas. The female we observed in Umiujaq was carrying prey, which suggests that a nest may have been nearby.

Purple Sandpipers were first documented as breeding on the Belcher Islands by Twomey (1942). In 1938, he collected 44 adults and 13 complete clutches (35 specimens and 7 clutches were from Tukarak Island). Clutch collection dates ranged from 9 June to 25 July 1938 (data courtesy of the Carnegie Museum of Natural History). Freeman (1970) discovered a nest containing four eggs on 8 July 1959 on an island in the Kasegalik River. Manning (1976) estimated that there were 4000 Purple Sandpipers on Kugong Island, the westernmost of the Belcher Islands. Freeman (1970) wrote (restated by Jehl 2004) that the Purple Sandpiper, along with the Semipalmated Plover, is "probably the commonest [breeding] shorebird" on the Belcher Islands. The fact that we saw just two birds suggests that large numbers may not breed regularly in the areas of Tukarak Island that we visited. Tukarak is a large island, and the areas we visited may not have been ideal breeding habitats for this and other shorebird species. Alternatively, the dates when we visited (mid to late July) are near the end of the breeding season for many sandpipers, and birds may have already departed the island. However, Twomey collected a full clutch on 25 July 1938, and Manning (1976) saw flocks of up to 150 Purple Sandpipers on Split Island (about $70 \mathrm{~km}$ to the northwest of Tukarak Island) in early August 1973, and he collected a male with four downy young there on 3 August. A thorough survey of all the Belcher Islands would be required to develop a clear understanding of their current breeding status. The Semipalmated Plover, Semipalmated Sandpiper, and Red-necked Phalarope also nest on the Belcher Islands (Todd 1963; Godfrey 1986); however, we observed only the plovers.

The single summer record for Least Sandpiper (Calidris minutilla) on the Belcher Islands is an observation of one nest by Twomey (1942) on Tukarak Island. Even though we did not observe any Least Sandpipers and Godfrey (1986) indicates that they do not nest on the Belcher Islands, further fieldwork could reveal that they are occasional breeders, as they are known to nest around Lac Guillaume-Delisle (Todd 1963; KRG 2007).

The sightings of adult Great Black-backed Gulls were noteworthy because known breeding colonies are quite distant: at Akimiski Strait, James Bay, $350 \mathrm{~km}$ south of the Belcher Islands (Eckert 2007; Dunn and Alderfer 2011) and $1400 \mathrm{~km}$ (by the coastline) northeast at the mouth of the Rivière aux Feuilles in Ungava Bay (Good 1998). The Belcher Islands could be colonized in the near future as nesting at Akimiski Strait was documented for the first time in 2007 (Eckert 2007). The Great Black-backed Gull is undergoing rap- 
id range expansion throughout eastern North America (Good 1998).

We did not observe Arctic Terns. Arctic Tern populations declined between the 1980s and 1997 in the three northern regions (Sleeper, Split, and Laddie Islands) of the Belcher Islands (Gilchrist and Robertson 1999). Only 19 of the 431 islets in that region had nesting terns in 1997. This decline is attributed either to winter mortality or to emigration out of the Belcher Islands as a response to egging or disturbance by residents of Sanikiluaq, the only village on the islands. The tern surveys, summarized by Gilchrist and Robertson (1999), were not made on Tukarak Island, presumably because Arctic Terns are not known to nest on this island.

The nesting Peregrine Falcons we observed at Laddie Harbour belonged to the tundra subspecies, $P . f$. tundrius, based on the thin malar stripe, white upper breast, and extensive white in the auricular area. Freeman (1970) assigned the Peregrine Falcons he observed on Tukarak Island to $P$. $f$. anatum, although he provided no evidence to support this determination. The Nastapoka River represents a dividing line between $P$. f. tundrius on the north and P. f. anatum to the south (Murphy 1990).

The Hermit Thrushes seen in the Lac GuillaumeDelisle were extra-limital records, over $450 \mathrm{~km}$ north of the northern limit of their breeding range in southwestern Quebec (Godfrey 1986; Dellinger et al. 2012). Yves Aubrey (in KRG 2007) reports that they do nest in this area.

The Belcher Islands are the southernmost breeding site in North America for Snow Buntings (Plectrophenax nivalis), whereas the Yellow Warbler (Setophaga petechia) and White-throated Sparrow (Zonotrichia albicollis) are at the northern limits of their range at Lac Guillaume-Delisle. Sightings of these three species in the regions we visited are consistent with their known occurrence in eastern Canada.

In summary, the Belcher Islands are large, we only visited parts of Tukarak Island, and our fieldwork was brief - factors that make our survey less than complete. Clearly fieldwork in more areas and for longer periods is required to determine the current status of all breeding and summering birds there. The strategic location of the Belcher Islands and Lac GuillaumeDelisle - at the tree line and in a climatic zone where arctic conditions exist, as well as the fact that they support a number of species at the limits of their geographic range - make them useful sites for studying shifts in species' breeding ranges that could result from global climate change.

\section{Acknowledgements}

Our expedition was made possible by grants to Dominic Papineau and Marilyn Fogel from the Carnegie Institution of Canada, the National Aeronautical and Space Administration Astrobiology Institute, the W. M. Keck Foundation, and the Geophysical Laboratory of the Carnegie Institution of Washington. The authors and scientific team thank the municipality of Umiujaq, the Sakkuq Landholding Corporation, the Makivik Corporation, the Nunavut Research Institute, the Government of Nunavut (Department of Culture, Language, Elders and Youth), and the Qikiqtani Inuit Association for permission to conduct fieldwork on their territory. We are grateful to the captain and crew of the Kakivak for expert seamanship and, especially, to Arthur Elijassiapik for cheerful assistance in the field. Stephen Rogers, bird collection manager at the Carnegie Museum of Natural History, provided data on bird and egg specimens from the 1938 Twomey expedition. Jason Chartrand (GSC, Ottawa) provided GIS assistance in drafting Figure 1. David Shuford, Dominic Papineau and two anonymous reviewers made constructive comments on an early draft.

\section{Literature Cited}

Abraham, K. F., and G. H. Finney. 1986. Eiders of the eastern Canadian arctic. Pages 55-73 in Eider Ducks in Canada. Edited by A. Reed. Canadian Wildlife Service report series no. 47. Environment Canada, Ottawa, Ontario, Canada.

Burwash, L. T. 1927. The Eskimo, their country and its resources: economic survey of east coasts of Hudson Bay and James Bay from Richmond Gulf to Rupert House, including the Belcher and other adjacent islands, 1927. Department of the Interior, Northwest Territories and Yukon Branch, Ottawa, Ontario, Canada.

Comiso, J. C. 2003. Warming trends in the arctic from clear sky satellite observations. Journal of Climate 16: 34983510 .

Dellinger, R., P. B. Wood, P. W. Jones, and T. M. Donovan. 2012. Hermit Thrush (Catharus guttatus). In The Birds of North America Online. Edited by A. Poole. Cornell Lab of Ornithology, Ithaca, New York, USA. Accessed 20 September 2014. http://bna.birds.cornell.edu/bna/species 1261.

Dunn, J. L., and J. Alderfer. 2011. Field Guide to the Birds of North America. National Geographic Society, Washington, D.C., USA.

Eckert, C. 2007. Northern Canada regional report. North American Birds 61: 601-602.

Freeman, M. M. R. 1970. The birds of the Belcher Islands, N.W.T., Canada. Canadian Field-Naturalist 84: 277-285.

Gilchrist, H. G., and G. J. Robertson. 1999. Population trends of gulls and Arctic Terns nesting in the Belcher Islands, Nunavut. Arctic 52: 325-331.

Godfrey, W. E. 1986. The Birds of Canada. Revised edition. National Museums of Canada, Ottawa, Ontario, Canada.

Good, T. P. 1998. Great Black-backed Gull (Larus marinus). In The Birds of North America Online. Edited by A. Poole. Cornell Lab of Ornithology, Ithaca, New York, USA. Accessed 20 September 2014. http://bna.birds.cornell.edu /bna/species/330.

Jehl, Jr., J. R. 2004. Birdlife of the Churchill Region: Status, History, Biology. Trafford Publishing, Victoria, British Columbia, Canada.

Jetz, W., D. S. Wilcove, and A. P. Dobson. 2007. Projected impacts of climate and land-use change on the global diversity of birds. PLoS Biol 5(6): e157. 
KRG (Kativik Regional Government). 2007. Lacs-Guillaume-Delisle-et-à-l'Eau-Claire Park Project: status report. Kativik Regional Government, Renewable Resources, Environmental and Land Use Planning Department, Parks Section, Kuujjuaq, Quebec.

Lumsden, H. G. 1975. The Whistling Swan in James Bay and the southern region of the Hudson Bay. Arctic 28: 194-200.

Manning, T. H. 1946. Bird and mammal notes from the east side of Hudson Bay. Canadian Field-Naturalist 60: 71-85.

Manning, T. H. 1976. Birds and mammals of the Belcher, Sleeper, Ottawa and King George Islands, Northwest Territories. Canadian Wildlife Service Occasional Papers 28: 1-42, maps, tables.

Murphey, J. E. 1990. The 1985-1986 Canadian peregrine falcon, Falco peregrinus, survey. Canadian Field-Naturalist 104: 182-192.

Richards, J. M., and A. W. White. 2008. Birds of Nunavut: a checklist. J. M. Richards, Orono, Ontario, Canada, and A. W. White, Jackson, Wyoming, USA.

Robertson, G. J., and H. G. Gilchrist. 1998. Evidence of population declines among Common Eiders breeding in the Belcher Islands, Northwest Territories. Arctic 51: 378-385.

Robertson, G. J., and R. I. Goudie. 1999. Harlequin Duck (Histrionicus histrionicus). In The Birds of North America Online. Edited by A. Poole. Cornell Lab of Ornithology, Ithaca, New York, USA. Accessed 20 September 2014. http://bna.birds.cornell.edu/bna/species/466.

Savard, J-P. L., D. Bordage, and A. Reed. 1998. Surf Scoter (Melanitta perspicillata). In The Birds of North America
Online. Edited by A. Poole. Cornell Lab of Ornithology, Ithaca, New York, USA. Accessed 21 October 2014. http: //bna.birds.cornell.edu/bna/species/363.

Serreze, M. C., J. E. Walsh, F. S. Chapin III, T. Osterkamp, M. Dyurgerov, V. Romanovsky, W. C. Oechel, J. Morison, T. Zhang, and R. G. Barry. 2000. Observational evidence of recent change in the northern high-latitude environment. Climatic Change 46: 159-207.

Sheaffer, S. E., R. A. Malecki, B. L. Swift, J. Dunn, and K. Scribner. 2007. Management implications of molt migration by the Atlantic Flyway resident population of Canada Geese, Branta canadensis. Canadian Field-Naturalist 121(3): 313-320.

Smith, K. G., S. R. Wittenberg, R. B. Macwhirter, and K. L. Bildstein. 2011. Northern Harrier (Circus cyaneus). In The Birds of North America Online. Edited by A. Poole. Cornell Lab of Ornithology, Ithaca, New York, USA Accessed 20 September 2014. http://bna.birds.cornell.edu /bna/species/210/

Todd, W. E. C. 1963. Birds of Labrador and Adjacent Areas. University of Toronto Press (with the Carnegie Museum), Toronto, Ontario, Canada. 819 pages.

Twomey, A. C. 1942. Needle to the North: The Story of an Expedition to Ungava and the Belcher Islands. Houghton Mifflin, Boston, Massachusetts, USA.

Received 15 March 2014

Accepted 1 May 2014 